\title{
Effect of Learning and Teaching Preference Approaches on Academic Performance among Malaysian Accounting Students
}

\author{
Maheran Zakaria ${ }^{1, *}$, Nur Ain Abdul Malek ${ }^{2}$ \\ ${ }^{1}$ Faculty of Accountancy, Universiti Teknologi MARA Kelantan, Malaysia \\ ${ }^{2}$ Academy of Language Study, Universiti Teknologi MARA Kelantan, Malaysia
}

Received September 7, 2019; Revised October 10, 2019; Accepted October 17, 2019

Copyright@2019 by authors, all rights reserved. Authors agree that this article remains permanently open access under the terms of the Creative Commons Attribution License 4.0 International License

\begin{abstract}
Academic performance is an important indicator of a student's achievement in accomplishing educational objectives specifically for learning and teaching. Many factors have been linked to academic performance; however, there are inconclusive results over as to whether individual factor contributes the most effect. In pursuit of this, the study aims to decipher students' academic performance in relation to learning and teaching preference approaches. 324 sets of a questionnaire were randomly sent to first year undergraduate accounting students. From this amount, 263 students responded, contributing to 81.2 percent rate of response. The study adapted the Approaches and Study Skills Inventory for Students (ASSIST) questionnaire that identify three learning approaches (deep, strategic and surface), two teaching preference approaches (deep and surface) and academic performance achievements. Data were analysed using Sequential Equation Modelling (SEM) with Smart Partial Least Square (PLS) version two. Results indicate that learning approaches had a significant effect on academic performance in which strategic had the most effect, followed by deep and surface. In contrast, teaching preference approaches did not have any effect on academic performance. An understanding of the magnitude of effect of learning and teaching preference approaches at the early phase would assist the students, educators and institutions to optimize the best approach and eventually expedite Malaysian education quality to be on par with other developed nations in pursuit of academic excellence.
\end{abstract}

Keywords Academic, Approaches, Learning, Performance, Preference, Teaching, Student

\section{Introduction}

Students, educators and academic institutions have always been pressured for excellent academic performance. They are persistently bombarded by the public in exhorting reformation specifically in the emergence of digital and technology era. Education evolves, moving from traditional notion of learning and teaching to conception that is broader and nuanced. Educators are urged to optimize their expertise by choosing the best learning and teaching approaches that enhance student's academic performance.

Academic performance is the outcome of education objectives which indicates achievements of various parties namely students, educators and institutions. The achievements are demonstrated through knowledge elevation, changes in understanding and excellent academic results. Students with high academic performance would easily procure employment and have a better opportunity for academic advancement. For educators, high academic performance would reflect commitment, dedication and excellence in implementing proper strategies in learning and teaching. As for institutions, high academic performance portrays reputation, ranking and prestige in both local and global contexts. Hence, achieving academic performance excellence is an uphill battle and the utmost concern that requires concerted efforts by all educational communities.

Abundance of studies have examined various factors affecting academic performance, among others were learning styles (Albina, 2013; Bosnie \& Smith, 2015; Boohan \& Stevenson, 2014; Chermahini, Ghanbari \& Talab, 2013; Tsingos, Wilkinson), learning approaches (Al-Qahtani, 2015; Brown, White, Wakeling \& Naiker, 2015; Byrne, Flood, Willis, 2001; Booth, et al., 2013; Gappi, 2013; Lopez, Cervero, Suarez, Rodriquez, Pedro \& 
Esteban, 2013; Mlambo, 2011; Hall, Ramsey \& Raven, 2004; Sharon, 1999), teaching preference approaches (Hall et al., 2004; Booth, Luckett \& Mlasenovic, 1999), socio economic status (Ali, Haider, Khan \& Ahmad, 2013) and prior knowledge in subjects (Muller, Prinsloo \& De Plesus, 2007). However, all of these studies were carried out in foreign countries while local study remains scarce. The results might not be similar as there is no one-size-fits-all solution.

As the relationship between learning and teaching is complex, most of studies on learning have often been conducted independently of studies on teaching, leading to a gap between two communities of scholars. The first community focuses on the learning studies while the second focuses on the teaching studies. Nevertheless, learning and teaching are intertwined, as such a study is needed to bridge the knowledge gap between these intellectual communities.

Emulating prior studies while focusing on learning and teaching, the aim of this study is to contribute to the development of a body of research with the objective to decipher effect of student's learning and teaching preference approaches on academic performance within Malaysian context. Identifying the effect of these factors on academic performance at an early phase would help educators to choose the best learning and teaching preference approaches so that corrective measures, where possible can be implemented.

With this regard, the study is organized as follows. Initially, it starts with introduction and problem statement. Next, it reviews prior studies on the relationship between student's learning and teaching preference approaches in relation to academic performance. Later, it describes the methodology, followed by results and discussions. Finally, it offers management and academic implications as well as limitation of the study before ending with a conclusion.

\section{Literature Review and Hypotheses Development}

\subsection{Academic Performance}

Academic performance is the extent of students, educators and institutional achievement in relation to short or long-term educational goals which serves as an important key performance indicator in education. Every student exhibits different academic performance due to differences in a multitude of factors. Amongst the most frequent factors are learning and teaching preferences approaches. According to Booth, Lucket and Madenovic (1999), learning approach had an utmost effect on student's academic performance.

Indeed, it is noted that abundance of studies have examined the effect of learning approaches (Al-Qahtani, 2015; Booth et al.,1999; Brown, et al., 2015; Byrne, et al.,
2001; Gappi, 2013; Hall et al., 2004; Lopez, et al., 2013; Mlambo, 2011; Varughese \& Fehring, 2009) and teaching preference approaches (Booth et al., 1999; Brown et al., 2015; Hall et al., 2004;) on academic performance. However, evidences had also found inconclusive results on the effect of these factors on academic performance.

\subsection{Learning Approaches}

Learning approaches are construed to learning orientations adopted by a student in the process of acquiring knowledge. Every student has his or her own approach, style and preference which are distinct from one to another. According to Ramsden (1992), learning approaches are not individual characteristics or personality of a student, rather, they described a process of how the student acquire and retain knowledge.

\subsection{Deep, Surface and Strategic Approaches}

Marton and Saljo (1976) identified two different learning approaches that relate to academic performance, namely deep and surface. A student who strives to reach higher level of understanding from what he or she learns is classified as a deep approach. On the other hand, a surface approach student refers to one who acquires and is satisfied with low level of understanding. A third learning approach was identified by Ramsden (1979) known as strategic approach. A student with this approach would strategize his or her learning capabilities towards attaining the best possible grades.

Later, Tait, Entwistle and McCune (1997) developed the Approaches and Study Skills Inventory for Students (ASSIST). This instrument identifies three student learning approaches namely deep, surface or strategic and two teaching approaches preferred by students that are deep and surface. A student who adopts a deep approach for his or her learning orientation resorts to understand a subject in detail due to personal commitment to learning. He or she would more likely to have better acquisition and retention of knowledge.

A student who employs a surface approach on the other hand, would be satisfied with little knowledge or for him or her, learning is just to grasp concepts. The process of learning is external to the student in which contemplating tasks as well as answering examination extremely relies on material and memorizations. On the other hand, a student who engages a strategic approach would embrace knowledge by giving close attention to what would be tested in the examination. The objective is to obtain the highest grades and therefore managing time optimally by putting maximum effort in delivering maximum effect. Indeed, the strategic approach student is more likely to obtain high score in academic performance, followed by deep and surface approach (Biigs, 1987). 


\subsection{Teaching Preference Approaches}

\subsubsection{Deep and Surface Approaches}

There are two approaches of teaching preferred by students namely deep and surface (Marton \& Saljo, 1976). A student who prefers deep teaching approach is prone to explore external knowledge. Despite focusing on textbooks' contents, the student favours educators who are able to provide explanation beyond lecture notes. According to Biggs (1987), a student who prefers deep teaching approach has more interest to learn the subject in detail and thus, he or she is more likely to have a better academic outcome.

On the other hand, a student who prefers surface teaching approach would limit his or her knowledge within textbooks. He or she is satisfied with little knowledge, whereby, for him or her teaching is for disseminating, imparting information and grasping concepts.

\subsubsection{Effect of Learning and Teaching Preference Approaches on Academic Performance}

Despite immense studies indicate that learning and teaching preference approaches had a significant effect on academic performance (Al-Qahtani, 2015; Booth et al.,1999; Brown et al, 2015; Byrne, et al., 2001; Hall et al., 2004; Lopez, et al., 2013; Mlambo, 2011), few studies show otherwise in that the effect is insignificant (Booth et al., 1999; Gappi; 2013; Wilkinson et al., 2014).

Al-Qahtani (2015) investigated the effect of 166 first year undergraduate medical students' learning approaches on academic performance in Saudi Arabia. He found that students' learning approaches were more likely to affect academic performance. The results are consistent with Booth et al., (1999) that gauged learning and teaching preference approaches on academic performance of 394 undergraduate accounting students from Macquarie and New South Wales universities in Australia. This study compared the results with a prior study on Australian Arts, Studies, Education and Science students from the same universities. The study found a positive relationship between the variables and the former results show that excellent students had relatively higher strategic and deep learning approaches. Surface approach was found to be associated with less successful academic performance. However, no relationship was found for teaching preference approaches and academic performance.

Brown, et al., (2015) examined the effect of learning approaches on academic performance among 103 undergraduate students of an introductory chemistry course in New Zealand using the ASSIST. The study found that there was a positive relationship between the variables. Furthermore, female students were more likely to adopt a surface approach. Additionally, male students demonstrated higher score for strategic learning as opposed to female students and thus they were more likely to have better grades. On the other hand, Gappi (2013) who carried out an investigation on 131 undergraduate students in Bahrain indicated otherwise. He found that both learning and teaching preference approaches did not have a significant effect on academic performance.

Lopez et al., (2013) assessed the effect of learning and teaching preference approaches on academic performance of 148 excellent students selected from nine centers of the Polytechnic University of Valencia in Spain. They compared the results with a prior study conducted on 133 average students from the same centers. The study indicates a positive relationship between variables and concluded that higher academic performance was associated with deep approach whilst surface approach was related to lower academic performance for both learning and teaching preference approaches.

In contrast a cross sectional study conducted among first year medical and dental students at Queen University, Belfast, in the UK on the effect of learning teaching preferences on academic performance indicates that there was no relationship between the learning and teaching preference approaches with academic performance (Wilkinson et al., 2014). The study concluded that despite the learning and teaching preference approaches of students vary, they had trivial effect on academic performance.

Although there are inconclusive results on the effect of learning and teaching preference approaches on academic performance, the studies that supported are more substantial (Al-Qahtani, 2015; Brown et al, 2015; Lopez et al. 2013; Varughese \& Fehring; 2009) as compared to those that opposed (Wilkinson et al., 2014; Gappi; 2013; Booth et al., 1999). As such, emulating these prior studies, the following two hypotheses were formulated, and the research model is depicted in Figure 1.

H1: Student's learning approach has a positive effect on academic performance.

H2: Student's teaching preference approach has a positive effect on academic performance. 


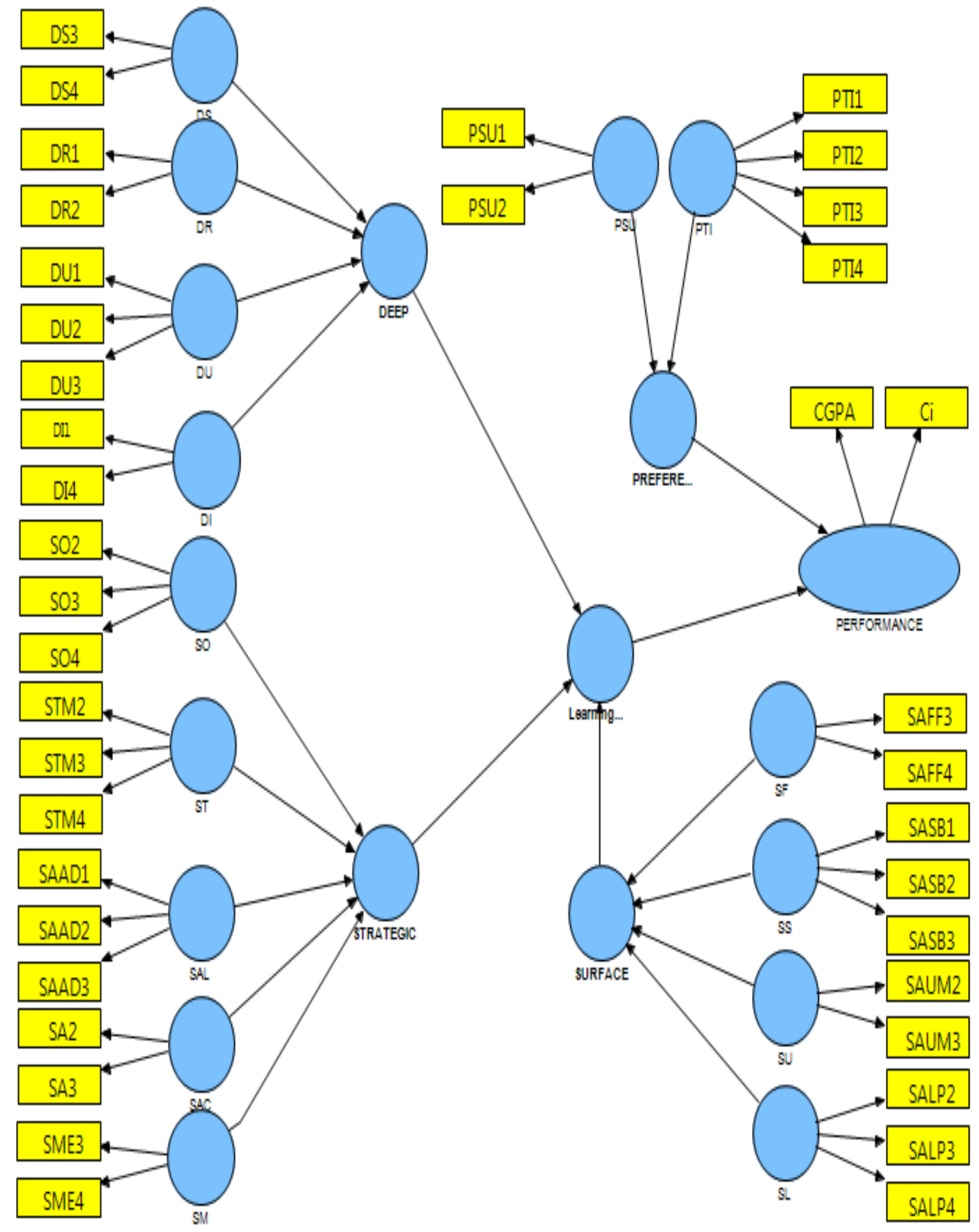

Figure 1. The proposed model 


\section{Method}

\subsection{Samples}

The study employed a cross-sectional research design using self-administered questionnaire adapted from the ASSIST. The population of this study was first year undergraduate accounting students from one of Malaysian public universities. Out of 400 students, 324 students were randomly selected by the system. The copies of questionnaire were e-mailed to the selected students. Before completing the survey, they were reminded to state name and student number for data references. This was to ease the process of cross checking with the university's record system if necessary. The students were explained on the purpose of conducting the survey and assured of the confidentiality and anonymity of information which is solely for research purposes. The students were also informed to respond within 2 weeks. After 3 weeks of no reply, a gentle reminder was e-mailed to them on the importance of their response to the education communities. A total of 263 responses were received after a month, accounted for 81.2 percent rate of response.

\subsection{Measurements}

\subsubsection{Learning and Teaching Instruments}

Numerous instruments have been developed to measure the learning and teaching, including Visual, Aural, Read/Write, Kinesthetic learning-styles inventory (VARK - Fleming \& Mills, 1992), Inventory of Learning Styles in Higher Education (ILS-Vermunt, 1994), Approaches and Study Skills Inventory for Students (ASSIST - Tait, Entwistle \& McCune, 1997) and motivated strategies for learning questionnaire (MSLQ - Zeegers, 2001). The VARK and ILS were developed to measure students' learning styles, while the MSLQ measures the motivation impact on students. Despite that these instruments are excellent, they only cater for one education domain namely learning. ASSIST on the other hand, is more comprehensive in which the instrument measured three education domains namely learning, teaching and academic performance. Based on these features, ASSIST was adapted with minimal addition by this study to measure the underlying constructs depicted in the research model.

\subsubsection{Approaches and Study Skills Inventory for Students} (ASSIST)

The ASSIST had been adopted by bountiful of studies to measure student's learning and teaching preference approaches (Brown et al., 2015; Enstwistle \& Ramden, 1983; Ramsden \& Enstwistle, 1981). Richardson (2011) opines that the ASSIST is the most widely used tested questionnaires or instruments on student's learning and teaching preferences approaches as well as academic performance.

\subsubsection{Measurements of Variables}

The ASSIST has four sections. Section A consists of 6 items measuring conceptions of learning; reducing knowledge, personal understanding and development. Section B measures the learning approaches. Section C consists of 8 items measuring the teaching preference approaches. This is then followed by section $\mathrm{D}$ that is background information and academic performance. The response format utilises a five-point Likert scale ranging from 1 (Disagree) to 5 (Agree).

\subsection{Learning Approaches}

Learning approaches are measured by 52 items. The instrument identifies three learning approaches namely deep, surface and strategic. The deep approach consists of 4 dimensions that are seeking meaning (4 items), relating ideas (4 items), use of evidence (4 items) and interest in ideas (4 items), totalling to 16 items. The surface approach comprises of 4 dimensions; lack of understanding (4 items), unrelated memorising (4 items), syllabus-boundless (4 items) and fear of failure (4 items), with a total of 16 items. Finally, the strategic approach has 5 dimensions that are organised studying (4 items), time management (4 items), alertness to assessment demands (4 items), monitoring effectiveness (4 items) and achieving (4 items), accounted for 20 items. The students' score would determine which approach they were more likely prone to either deep, surface or strategic. One who obtains the highest score for deep as opposed to surface and strategic approach is classified as a deep learning approach. Table 1 depicts the subscales of learning approaches.

Table 1. Subscales of Learning Approaches

\begin{tabular}{|c|l|l|l|}
\hline Subscales & Deep Approach & Surface Approach & Strategic Approach \\
\hline \multirow{4}{*}{ Learning } & Seeking meaning & Lack of understanding & Organised studying \\
& Relating ideas & Unrelated memorising & Time management \\
& Use of evidence & Syllabus-boundless & Alertness to assessment demands \\
& Interest in ideas & Fear of failure & Monitoring effectiveness \\
\hline
\end{tabular}




\subsection{Teaching Preferences Approaches}

Section $\mathrm{C}$ entails the teaching preference with two approaches namely deep and surface. The deep approach consists of encouraging understanding (4 items) while the surface approach constitutes a dimension of namely transmitting information (4 items) for deep and surface approach respectively, totalling to 8 items. A student who obtains higher score in deep approach dimension (supporting understanding) is classified as a deep approach, whilst, a surface approach is that who obtains higher score in surface approach dimension (transmitting information). Table 2 depicts the subscales of teaching preference approaches.

Table 2. Subscales of Teaching Preference Approaches

\begin{tabular}{|c|c|c|}
\hline Subscales & Deep Approach & Surface Approach \\
\hline Teaching & Supporting & Transmitting \\
Preference & understanding & information \\
\hline
\end{tabular}

\section{Results and Discussion}

\subsection{Demographic Profile}

Table 3. Respondents’ Demographic Profile

\begin{tabular}{|c|c|c|c|}
\hline Profile & Categories & Frequency & Percent \\
\hline \multirow{2}{*}{ Gender } & Male & 55 & 20.9 \\
\hline & Female & 208 & 79.1 \\
\hline \multirow{4}{*}{ Age } & 21 & 27 & 10.3 \\
\hline & 22 & 203 & 77.2 \\
\hline & 23 & 30 & 11.5 \\
\hline & Above 24 & 3 & 1.0 \\
\hline \multirow{3}{*}{$\begin{array}{c}\text { Prior } \\
\text { Knowledge } \\
\text { of } \\
\text { Accounting }\end{array}$} & Diploma & 237 & 90.1 \\
\hline & Matriculation/Foundation & 13 & 4.9 \\
\hline & SPM/ O level & 13 & 4.9 \\
\hline \multirow{3}{*}{$\begin{array}{l}\text { CGPA } \\
\text { Category }\end{array}$} & $\begin{array}{c}\text { Third Class }(2.00-2.29) \\
\text { Second Class Lower } \\
\text { Honors }(2.30-2.99) \\
\end{array}$ & $\begin{array}{c}4 \\
76\end{array}$ & $\begin{array}{l}1.5 \\
28.9\end{array}$ \\
\hline & $\begin{array}{l}\text { Second Class Upper } \\
\text { Honors }(3.00-3.49)\end{array}$ & 156 & 59.3 \\
\hline & $\begin{array}{l}\text { First Class Honors (3.50 - } \\
4.00)\end{array}$ & 27 & 10.3 \\
\hline
\end{tabular}

$\mathrm{N}: 263$

The results indicate that 208 or 79.1 percent of respondents were female while the remaining 55 or 20.9 percent were male. In terms of age, majority of the respondents were in the age of 22 (203 or 77.2 percent), followed by the age of 21 (27 or 10.3 percent), 23 (30 or 11.5 ) and above 24 ( 3 or 1.0 percent). The results further indicate that 237 respondents or 90.1 had acquired prior knowledge of accounting during their diploma studies. 13 respondents or 4.9 percent acquired prior knowledge during matriculation or foundation and the remaining 13 respondents or 4.9 percent had acquired during Sijil
Pelajaran Malaysia (SPM) ( SPM is equivalent to General Certificate of Education at Ordinary level or known as GCE O-level). Most of the respondents achieved Cummulative Grade Point Average (CGPA) of 3.00-3.49 (156 or 59.3 percent), followed by $2.30-2.99$ (76 or 28.9 percent), $3.50-4.00$ (27 or 10.3 percent) and 2.00- 2.29 (4 or 1.5 percent). Table 3 depicts the demographic profile of the respondents.

\subsection{Normality Test}

To ensure that data are normally distributed, a normality test was conducted. Results showed that the means value of underlying constructs was between the range of 2.75 to 4.01. Kurtosis score was from the lowest of 0.41 to the highest of 0.75 . The standard deviation was within the score of 1.12 to 1.43 . The scale was within normal distribution of -2 and +2 and therefore the data were acceptable for normal univariate distribution (George \& Mallery, 2010).

\subsection{Assessment of a Measurement Model}

The Smart Partial Least Square (PLS) version 2.0 was adopted to evaluate the model by estimating the parameters in the outer and inner model (Ringle, Wende \& Will, 2005). For this proposed research model, the PLS-SEM algorithm converged after 14 iterations, which indicates that there was no abnormal issue with the data. The PLS path modelling was applied for this study, with a path weighing scheme for the inside approximation of 200 resampling to obtain standard errors of the estimates. The PLS requires two evaluations namely measurement and structural model (Anderson \& Gerbing, 1988).

\subsection{Measurement Model}

In the measurement model, the data were assessed in terms of reliability and validity. For this purpose, three assessments were conducted namely convergent validity, reliability analysis and discriminant validity. Reliability was assessed through composite indicator and internal consistency while validity was assessed through convergent and discriminant validity.

\subsection{Reliability Analysis}

The reliability analysis is to measure whether items consistently represent the constructs they are measuring (Sekaran \& Bogie, 2010). Results indicate that Cronbach alpha values of all constructs were between 0.65 to 0.97 , except for CGPA. These values were higher than the value of 0.6 suggested by Sekaran and Bogie (2010). Although the values of the CGPA Cronbach Alpha were below the suggested level, they were maintained as they surpassed the composite reliability requirement level. 


\subsection{Composite Reliability}

The composite reliability (CR) is suggested to replace Cronbach's alpha in assessing the internal consistency reliability in PLS-SEM (Hair, Anderson, Tatham \& Black, 2012: Bagozzi \& Yi, 1988). Composite reliability that is higher than 0.7 is preferred and for exploratory study, a value of 0.6 is considered acceptable (Bagozzi \& Yi, 1988). The results indicate that all composite reliability values were higher than 0.6 indicating acceptable levels of internal consistency reliability had been demonstrated among all reflective latent constructs.

Table 4. Results Summary for Measurement Model

\begin{tabular}{|c|c|c|c|c|c|c|}
\hline \multicolumn{2}{|c|}{ Construct } & Item & Loadings & Reliability & $A V E$ & $C R$ \\
\hline \multirow{9}{*}{$\begin{array}{l}\text { Learning Approach } \\
\text { (Deep) }\end{array}$} & \multirow{2}{*}{ Interest in ideas } & DI1 & 0.730 & 0.533 & 0.548 & 0.708 \\
\hline & & DI4 & 0.751 & 0.564 & & \\
\hline & \multirow{2}{*}{ Relating ideas } & DR1 & 0.787 & 0.619 & 0.655 & 0.791 \\
\hline & & DR2 & 0.831 & 0.691 & & \\
\hline & \multirow{2}{*}{ Seeking meaning } & DS3 & 0.796 & 0.633 & 0.642 & 0.782 \\
\hline & & DS4 & 0.807 & 0.652 & & \\
\hline & \multirow{3}{*}{ Use of evidence } & DU1 & 0.741 & 0.549 & 0.511 & 0.758 \\
\hline & & DU2 & 0.722 & 0.521 & & \\
\hline & & DU3 & 0.680 & 0.463 & & \\
\hline \multirow{13}{*}{$\begin{array}{l}\text { Learning Approach } \\
\text { (Strategic) }\end{array}$} & \multirow{2}{*}{ Achieving } & SA2 & 0.680 & 0.463 & 0.629 & 0.772 \\
\hline & & SA3 & 0.680 & 0.463 & & \\
\hline & \multirow{3}{*}{$\begin{array}{l}\text { Alertness to assessment } \\
\text { demands }\end{array}$} & SAAD1 & 0.734 & 0.538 & 0.520 & 0.765 \\
\hline & & SAAD2 & 0.749 & 0.561 & & \\
\hline & & SAAD3 & 0.679 & 0.461 & & \\
\hline & \multirow{2}{*}{ Monitoring effectiveness } & SME3 & 0.823 & 0.678 & 0.629 & 0.772 \\
\hline & & SME4 & 0.823 & 0.678 & & \\
\hline & \multirow{3}{*}{ Organised studying } & $\mathrm{SO} 2$ & 0.680 & 0.463 & 0.570 & 0.798 \\
\hline & & $\mathrm{SO} 3$ & 0.680 & 0.463 & & \\
\hline & & $\mathrm{SO} 4$ & 0.680 & 0.463 & & \\
\hline & \multirow{3}{*}{ Time management } & STM2 & 0.823 & 0.678 & 0.524 & 0.764 \\
\hline & & STM3 & 0.823 & 0.678 & & \\
\hline & & STM4 & 0.823 & 0.678 & & \\
\hline \multirow{10}{*}{$\begin{array}{l}\text { Learning Approach } \\
\text { (Surface) }\end{array}$} & \multirow{2}{*}{ Fear of failure } & SAFF3 & 0.756 & 0.571 & 0.660 & 0.795 \\
\hline & & SAFF4 & 0.866 & 0.749 & & \\
\hline & \multirow{3}{*}{ Lack of understanding } & SALP2 & 0.671 & 0.451 & 0.530 & 0.771 \\
\hline & & SALP3 & 0.754 & 0.568 & & \\
\hline & & SALP4 & 0.756 & 0.571 & & \\
\hline & \multirow{3}{*}{ Syllabus-boundless } & SASB1 & 0.690 & 0.477 & 0.484 & 0.738 \\
\hline & & SASB2 & 0.694 & 0.481 & & \\
\hline & & SASB3 & 0.703 & 0.494 & & \\
\hline & \multirow{2}{*}{ Unrelated memorizing } & SAUM2 & 0.786 & 0.618 & 0.628 & 0.771 \\
\hline & & SAUM3 & 0.786 & 0.617 & & \\
\hline \multirow{2}{*}{$\begin{array}{l}\text { Teaching Preference } \\
\text { (Deep) }\end{array}$} & \multirow{2}{*}{ Supporting understanding } & PSU1 & 0.792 & 0.628 & 0.656 & 0.792 \\
\hline & & PSU2 & 0.827 & 0.684 & & \\
\hline \multirow{4}{*}{$\begin{array}{l}\text { Teaching Preference } \\
\text { (Surface) }\end{array}$} & \multirow{4}{*}{ Transmitting information } & PTI1 & 0.690 & 0.476 & 0.553 & 0.831 \\
\hline & & PTI2 & 0.767 & 0.589 & & \\
\hline & & PTI3 & 0.830 & 0.689 & & \\
\hline & & PTI4 & 0.823 & 0.678 & & \\
\hline \multirow{2}{*}{ Academic Performance } & \multirow{2}{*}{ Performance } & CGPA & 0.535 & 0.112 & 0.542 & 0.656 \\
\hline & & Perceived Performance & 0.986 & 0.972 & & \\
\hline
\end{tabular}




\subsection{Convergent Validity}

Convergent and discriminant validity were employed to measure the constructs validity. Emulating Hair et al. (2010), the convergent validity was assessed based on two measurements that were factor loading and average variances extracted (AVE). A basic rule of thumb for an acceptable measurement model is that all the item loadings for the first order latent variables are at least 0.5 (Chin, Marcolin \& Newsted, 1997). Any items that have loadings fall below 0.5 are subjected to be eliminated from the model. The results indicate that in the final models, all items loading were more than 0.5. The AVE indicate that all of the values were greater than the suggested acceptable threshold value of 0.5 (Bagozzi \& Yi, 1988) and hence the convergent validity was accomplished. The results are depicted in Table 4.

\subsection{Discriminant Validity}

The discriminant validity indicates that the constructs are not supposed to be related among construct. To establish the discriminant validity as suggested by Fornell and Larcker (1981), the "square root" of AVE of each latent variable should be greater than the correlations among the latent constructs. These values are shown in 'bold' numbers in the diagonal of Table 5, indicating that the discriminant validity was well established. Tenenhaus, Vinz and Lauro, (2005) suggested that a global fit measure for path modeling, namely the global fit measures (GoF), is used to access the validity of a PLS model. The general baseline values are GoFsmall $=0.1$, GoFmedium $=0.25$, and GoFlarge $=0.36$. Hence, for the final model, a GoF value of 0.23 was obtained, which was at the end margin of between the cutoff values 0.1 and 0.25 . The value was considered to have a small to medium effect size of $R^{2}$ and thus concluded that the model was acceptable.

Table 5. Discriminant Validity

\begin{tabular}{|c|c|c|c|c|c|c|c|c|c|c|c|c|c|c|c|c|}
\hline Construct & {$[1]$} & {$[2]$} & {$[3]$} & {$[4]$} & {$[5]$} & {$[6]$} & {$[7]$} & {$[8]$} & {$[9]$} & {$[10]$} & {$[11]$} & {$[12]$} & {$[13]$} & {$[14]$} & {$[15]$} & {$[16]$} \\
\hline$[1]$ DI & 0.74 & & & & & & & & & & & & & & \\
\hline [2] DR & 0.30 & 0.81 & & & & & & & & & & & & & \\
\hline [3] DS & 0.23 & 0.30 & 0.80 & & & & & & & & & & & & \\
\hline [4] DU & 0.36 & 0.33 & 0.42 & 0.71 & & & & & & & & & & & \\
\hline [5] SAC & 0.28 & 0.21 & 0.26 & 0.40 & 0.79 & & & & & & & & & & \\
\hline [6] SAL & 0.35 & 0.28 & 0.30 & 0.35 & 0.41 & 0.72 & & & & & & & & & \\
\hline [7] SM & 0.20 & 0.16 & 0.17 & 0.18 & 0.15 & 0.19 & 0.79 & & & & & & & & \\
\hline [8] SO & 0.02 & 0.14 & 0.09 & 0.05 & -0.13 & -0.02 & 0.31 & 0.75 & & & & & & & \\
\hline [9] ST & 0.30 & 0.24 & 0.37 & 0.41 & 0.40 & 0.44 & 0.21 & -0.17 & 0.72 & & & & & & \\
\hline [10] SF & 0.36 & 0.22 & 0.36 & 0.29 & 0.51 & 0.45 & 0.24 & -0.03 & 0.37 & 0.81 & & & & & \\
\hline [11] SL & 0.16 & 0.14 & 0.13 & 0.10 & 0.14 & 0.21 & 0.31 & 0.24 & 0.11 & 0.26 & 0.73 & & & & \\
\hline [12] SS & 0.29 & 0.32 & 0.32 & 0.25 & 0.46 & 0.38 & 0.11 & -0.07 & 0.35 & 0.64 & 0.16 & 0.70 & & & \\
\hline [13] SU & 0.17 & 0.14 & 0.12 & 0.14 & 0.02 & 0.06 & 0.36 & 0.49 & -0.08 & 0.11 & 0.33 & 0.14 & 0.79 & & \\
\hline [14] PSU & 0.20 & 0.15 & 0.16 & 0.19 & 0.12 & 0.14 & 0.08 & -0.07 & 0.13 & 0.09 & 0.04 & 0.14 & -0.06 & 0.81 & \\
\hline [15] PTI & 0.10 & 0.00 & 0.13 & 0.18 & 0.16 & 0.17 & 0.07 & -0.08 & 0.04 & 0.11 & 0.14 & 0.03 & 0.09 & 0.24 & 0.74 & \\
\hline [16] & 0.07 & 0.09 & 0.14 & 0.20 & 0.33 & 0.17 & 0.09 & -0.06 & 0.24 & 0.25 & 0.09 & 0.27 & 0.01 & -0.02 & 0.02 & 0.74 \\
\hline Performance & & &
\end{tabular}

Note: Diagonal represents the square root of Average Variance Extracted (AVE) while the other entries represent squared correlations 


\subsection{Structural Model}

The structural model examines the causal relationships between constructs through the values of path coefficient and $R^{2 .}$ (Sang \& Bogie, 2010). After all the reliability and validity analyses have met the acceptable criteria of the measurement model, the data were further examined in a structural model. As the number of bootstrapping subsamples was large, the results were considered normally distributed and as such, the normal (Gaussian) quantile was used to determine the critical t-values. Later, the results were proceeded to test the significance of the path coefficients. A simple rule of thumb, for a two-sided test with significance level of $5 \%$, the cut-off critical $\mathrm{t}$-value is 1.96. In other words, any empirical t-value of higher than the cut-off value indicates that the path coefficient is significantly different from 0 .
The results indicate the value of $R^{2}$ was 10.3 percent. In other words, 10.3 percent of student's academic performance was explained by the variance in learning and teaching preference approaches. The results further show that all values of the inner model exceeded the cut-off value of 1.96 indicating a significant value different from 0 . This shows that the learning approaches had a significant effect on academic performance $\left(\beta_{1}=0.328, p<0.01\right)$. In terms of magnitude of effect, strategic was the highest $\left(\beta_{1}=0.696\right.$, $p<0.01)$, followed by deep $\left(\beta_{1}=0.352, p<0.01\right)$ and surface was the lowest $\left(\beta_{1}=0.178, p<0.01\right)$. In contrast, the results indicate that teaching preference approaches had no significant effect on academic performance $\left(\beta_{1}=-0.053\right.$, $p<0.01)$. The t-value was 0.971 , lesser than the cut-off critical t-value of 1.96, indicating the path coefficient was not significantly different from 0 . Table 6 and Figure 2 indicate the structural model resulting from the PLS output.

Table 6. Path Coefficient and Hypotheses Testing

\begin{tabular}{|c|c|c|c|c|c|}
\hline Hypothesis & Description & Std. Beta & Std. Error & T-value & Assessment \\
\hline H1 & Learning Approaches -> Academic Performance & 0.328 & 0.066 & $4.945^{* *}$ & Supported \\
\hline & Strategic -> Learning Approaches & 0.696 & 0.045 & $15.436^{* *}$ & Supported \\
\hline & Deep -> Learning Approaches & 0.352 & 0.028 & $12.603^{* *}$ & Supported \\
\hline & Surface -> Learning Approaches & 0.178 & 0.081 & $2.208^{*}$ & Supported \\
\hline H2 & $\begin{array}{c}\text { Teaching Preference Approaches -> Academic } \\
\text { Performance }\end{array}$ & -0.053 & 0.055 & 0.971 & Not Supported \\
\hline
\end{tabular}

${ }^{*} p<0.0 .05, \mathrm{t}$ value is greater than $1.96 .{ }^{* *} p<0.01, \mathrm{t}$ value is greater than 2.33 . 


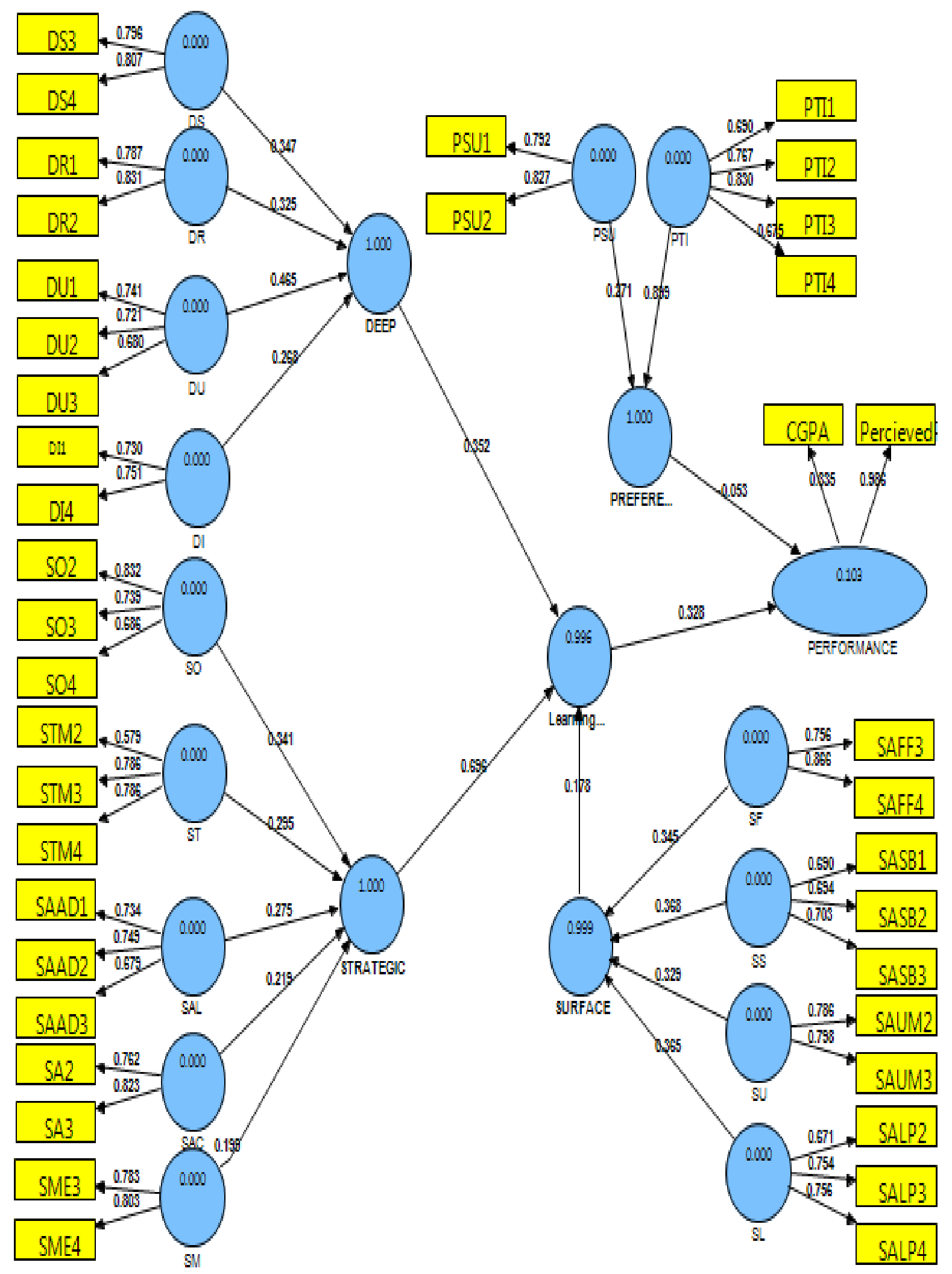

Figure 2. The structural model 


\section{Discussion}

This study hypothesized that learning approaches have a significant effect on academic performance. The results supported the hypothesis $1\left(\beta_{1}=0.328, p<0.01\right)$ and concurs with the work of prior studies (Al-Qahtani, 2015; Brown et al, 2015; Lopez et al., 2013; Varughese \& Fehring, 2009) that the student's learning approaches are more likely to have an effect on academic performance. The results further indicate that in terms of magnitude of effect, strategic recorded the highest score $\left(\beta_{1}=0.696, p<\right.$ $0.01)$, followed by deep $\left(\beta_{1}=0.352, p<0.01\right)$ and surface $\left(\beta_{1}=0.178, p<0.01\right)$ had the least score, indicating that the student who adopted strategic approach was more likely to obtain the highest academic performance, followed by deep and surface. This is consistent with the studies of Brown et al., (2015), Lopez et al., (2013), Varughese \& Fehring, (2009). However, the results did not support hypothesis $2\left(\beta_{1}=-0.053, p>0.01\right)$ that the teaching preference approaches have a significant effect on academic performance. The results are consistent with the studies of Wilkinson et al., (2014); Gappi, (2013); Booth et al., (1999) that teaching preferences approaches have no significant effect on academic performance.

\subsection{Implication to Management}

The results provide implications to management to formulate policies by designing curriculums and setting educational goals and rules that support the strategic learning approach. This would converge students with diverse backgrounds and personalities to foresee that strategic is the best learning approach and therefore strive to embrace it in pursuit of academic excellence.

The management is also suggested to offer individual support assistance to both students and educators. Any issue or conflict arising between them while shifting the learning paradigm from surface to deep or even strategic approach should be resolved amicably. Moreover, the management should assure educational infrastructure and facilities are conducive enough to support strategic learning approach in which the students are to be educated on time management, systematic study organization and motivation to achieve the highest possible grades in examinations.

\subsection{Implication to Academic}

The results provide implication to the body of knowledge of academic literature on the effect of learning approaches on academic performance. Students are agents in their learning, and they can be either passive or active. Passive leaners are those who acquire knowledge on surface for the sake of passing exam whilst active leaners are motivated for in-depth knowledge to excel in examinations. Deep and strategic learning approaches are related to greater success, while surface learning approach may put students at risk for poor academic performance.

The educators should facilitate the students moving from surface or passive absorption of information to active or deep engagement with information. Hence, it is the duty of educators to shift learning paradigm of the students from surface to deep or even strategic approach in accelerating the quality of academic performance.

\subsection{Limitation and Suggestion for Future Studies}

The data were collected through survey and analyzed using quantitative approach. In this context, the respondents were required to answer the adapted structured questionnaire namely the ASSIST. The instrument denied them to highlight their own learning preference approach. Instead, they were forced to rate the available learning approaches namely surface, deep and strategic. To overcome this, a qualitative approach is suggested to be conducted in this area of interest in which respondents are free to express their opinions on the learning approach without any restrictions. Perhaps, this may lead to the emergent of new learning approach concepts.

The study on the effect of learning and teaching preference approaches on academic performance has been the focus of many scholars across the nations. To increase the validity of the results, it is suggested that a comparative study should be conducted between two or more nations. It would be interesting to see the consistency or difference in the results that provide a better understanding on the learning and teaching preference approaches on academic performance. Hence, the difference (if any) should not be treated as obstacle to be confronted but as resource to be explored.

\section{Conclusions}

This study indicates that learning approaches had a significant effect on academic performance, but no significant effect was found between teaching preference approaches and academic performance. In terms of magnitude of effect, strategic approach had the most effect, followed by deep and surface. The study provides useful insights for students, educators and institutions to understand and comprehend the effect of learning and teaching preference approaches in relation to academic performance. In pursuit of academic excellence, the students should maneuver themselves to adopt the best learning approach. While, for educators, the discovery would help them to ponder on the best learning approach before implementing appropriate deliveries, activities, and assessments. Academic institutions on the other hand, should formulate initiatives, resources and infrastructure that support the best learning approach. The main aim is to alert the students on the importance of adopting the right 
learning approach for academic excellence. Hence, concerted efforts of students, educators and institutions are required, either acting individually or collectively to nurture the exact learning approach that eventually exacerbates the academic performance of the local students to be on par with other developed nations.

\section{Acknowledgements}

This study is self-funded, and the authors would like to thank all students who participated and the management of Universiti Teknologi MARA Kelantan. They also wish to express their gratitude towards Institute of Quality and Knowledge Advancement (InQKA), Universiti Teknologi MARA for providing continuous support in ensuring the publication of this research possible.

\section{REFERENCES}

[1] Albina, A.P. (2013). A study on learning styles and academic achievement of high school students. Research Paper, 2 (6), 1-10.

[2] Ali, S., Haider, Z., Munir, F., Khan, H., \& Ahmed, A. (2013). Factors contributing to the students' academic performance: A case study of Islamia University Sub-Campus. American Journal of Educational Research,1(8), 283-289.

[3] Al-Qahtani, M.F. (2015). Associations between approaches to study, the learning environment and academic achievement. Journal of Taibah University Medical Sciences. 10(1), 56-65.

[4] Andersen, J.C. \& Gerbing, D.W. (1988). Structural equation modelling in practice: A review and recommended two-step approach. Psychological Bulletin 103, 411-423.

[5] Approaches and Study Skills Inventory for Students (ASSIST) (1996). Edinburgh: Centre for Research on Learning and Instruction, University of Edinburgh.

[6] Bagozzi, R. P. \& Yi, Y. (1988). On the evaluation of structural equation models. Journal of the Academy of Marketing Science. 16, 74-94.

[7] Biigs, J.B. (1987). Student Approaches to learning and studying. Hawthorn, VIC: Australian Council for Education Research.

[8] Bisman, J. (2011). Engaged pedagogy: A study of the use of reflective journals in accounting. Assessment \& Evaluation in Higher Education, 36(3), 315-330.

[9] Booth, P., Luckett, P. \& Mlasenovic, R. (1999). The quality of learning in accounting education: the impact of approaches to learning on academic performance. Accounting Education, 8 (4), 272-300.

[10] Brown S., White, S., Wakeling, L. \& Naiker, M. (2015). Approaches and Study skills inventory for students (ASSIST) in an introductory course in Chemistry. Journal of University Teaching \& Learning Practice, 12(3), 1-12,
[11] Byrne, M., Flood, B., \& Willis, P. (2002). The relationship between learning approaches and learning outcomes: a study of Irish accounting students. Accounting Education, 11(1), 27-42.

[12] Chermahini, S.A., Ghanbari , A., \& Talab, M.C. (2013). Learning styles and academic english as a second-language class in Iran. Bulgarian Journal of Science Education Policy, 7(2), $322-333$.

[13] Chin, W. W., Marcolin, B. L., \& Newsted, P. R. (2003). A partial least squares latent variable modeling approach for measuring interaction effects: Results from a Monte Carlo simulation study and an electronic-mail emotion/adoption study. Information Systems Research, 14(2), 189-217.

[14] Davison, A. C., \& Hinkley, D. V. (1997). Bootstrap methods and their application. Cambridge, UK: Cambridge University Press.

[15] Entwistle, N.J., Hanley, M., \& Hounsell, D. (1979). Identifying distinctive approaches to studying. Higher Education, 8, 365-380.

[16] Entwistle, N.J. \& Ramsden, P. (1983). Understanding student learning. London: Croom Helm.

[17] Fornell, C. \& Larcker, D. F. (1981). Evaluating structural equation models with unobservable variables and measurement error. Journal of Marketing Research, 18(1), 39-50.

[18] Gappi, L.L. (2013). Relationships between learning style preferences and academic performance of students. International Journal of Educational Research and Technology. 4(2), 70-76.

[19] George, D., \& Mallery, M. (2010). SPSS for Windows Step by Step: A Simple Guide and Reference, 17.0 update (10a ed.) Boston: Pearson. What is the acceptable range of skewness and kurtosis for.... Available from: https://www.researchgate.net/post/What_is_the_acceptable _range_of_skewness_and_kurtosis_for_normal_distributio n_of_data [accessed Aug 8, 2017].

[20] Hair, J., Anderson, R., Tatham, R., \& Black, W. (2012) Multivariate data analysis (8th ed.). Upper Saddle River, NJ: Prentice Hall.

[21] Hall, M., Ramsay, A. \& Raven,J. (2004), Changing the learning environment to promote deep learning approaches in first-year accounting students. Accounting Education 13(4), 489-505.

[22] Hulland, J. (1999). Use of partial least squares (PLS) in strategic management research: A review of four recent studies. Strategic Management Journal, 20, 195-204.

[23] Laidra, K. Pullmann, H. Allik, J. (2007). Personality and Intelligence as predictors of academic achievement: A cross-sectional study from elementary to secondary school. Personality and individual differences, 42(3), 441-457.

[24] Lopez, B.G., Cervero, G. A. Suarez, Rodriguez,J.M.S, Pedro, E.G.F., \& Esteban.R.G. (2015). Learning styles and approaches to learning in excellent and average first-year university students. European Journal of Psychology of Education, 28(4), 1361-1379.

[25] Marton, F., \& Saljo, R. (1976). On qualitative differences in learning outcome and process. British Journal of 
Educational Psychology, 46, 4-11.

[26] Marton, F. \& Saljo, R. (1984). Approaches to learning. In F. Marton, D.Housell and N.J. Entwistle (eds). The experience of learning. Edinburg: Scottish Academic Press.

[27] Mlambo, V. (2011). An analysis of some factors affecting student academic performance in an introductory biochemistry course at the University of the West Indies. Carribean Teaching Scholar, 1(2), 79-92.

[28] Muller, H., Prinsloo, P., \& Du Plessis, A. (2007). Validating the profile of a successful first year accounting student. Meditari Accountancy Research. 15(1), 19-33.

[29] Montano, J.L.A., Gonzalez, J.M.G, Hassall, T., Joyce, J., Germanou, E., \& Asonitou, S. (2010). The approaches to learning of European accounting students. EuroMed Journal of Business, 5(3), 345-362.

[30] Neil D. F., Collen, M. (1992). Not another inventory, rather a catalyst for reflection' from to improve the academy, 11, 137-143. Nebraska - Lincoln Digital Commons: University of Nebraska.

[31] Nzesei M.M.(2015). A correlation study between learning styles and academic achievement among secondary school students in Kenya. Phd doctoral dissertation. University of Nairobi. Available at: http://erepository.uonbi.ac.ke/bitstre am/handle/11295/93142/Mutua_A+correlation+study. [accessed Aug 8,2017].

[32] Ramsden, P. (1979). Student learning research: retrospect and prospect. Higher Education Reseacrh and Development, 8, 411-427.

[33] Ramsden, P. (1992). Learning to teach in higher education. London: Routledge.

[34] Ramsden, P., Beswick, D.G., \& Bowden, J.A. (1986). Effect of learning skills interventions on first year university students' learning. Human Learning, 5(3), 151-164.

[35] Ramsden, P., \& Entwistle, N.J. (1981). Effects of academic departments on students' approaches to studying. British Journal of Educational Psychology, 51, 368-383.

[36] Richardson, J.T.E. (2011). Approaches to studying, conceptions of learning and learning styles in higher education. Learning and Individual Differences, 21, 288-293.

[37] Ringle, C., Wende, S., Will, A. (2005). Smart PLS 2.0 (Beta) Hamburg. Available at: http:www.smartpls.de.

[38] Sekaran, U. \& Bougie, R. (2010). Research methods for business: A skill building approach, London: Wiley

[39] Tabesh H., \& Hukai, D. (2012). Qualitative determinants of undergraduate academic performance: A case study. Journal of Higher Education Theory and Practice, 12(3), 29 $-34$.

[40] Tait, H., Entwistle, E., \& McCune, V. (1998). ASSIST: a reconceptualisation of the approaches to studying inventory. In C. Rust (Ed.), Improving student learning: improving students as learners (pp. 262-271). Oxford: the Oxford Centre for Staff and Learning Development.

[41] Tenenhaus, M., Vinz, C.Y.M. \& Lauro, C. (2005). PLS path modeling. Comput, 48(1), 159-205.

[42] Tsingos, C., Bosnic, S., Smith, L. (2015). Learning styles and approaches: Can reflective strategies encourage deep learning? Currents in Pharmacy Teaching and Learning, 7(4). 492-504.

[43] Varughese V.K. \& Fehring, H. (2009). Effective of students' approaches to learning on performance in two pedagogical Environments. International Education Studies, 2(4), 10-14.

[44] Vermunt J.D. (1994). Inventory of learning styles (ILS) in higher education. Department of Educational Psychology. Tilburg University, 1-10. Available at http: www.researchg ate.

[45] Wilkinson, T., Boohan M., \& Stevenson, M. (2014). Does learning style influence academic performance in different forms of assessment? Journal of Anatomy, 224(3). 304-308.

[46] Zeegers, P. (2001) Approaches to learning in science: a longitudinal study. British Journal of Educational Psychology 71(1), 115-132. 